その点てニニークな慨唭整といえよう。 しかし注架全くない点は珍らしい。大学

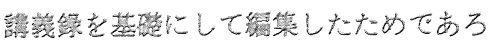
らか，女中て蔡者自身の説か否か不明の

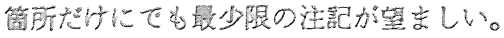

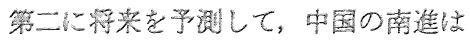
止はることか゚ないと兒通した点である。

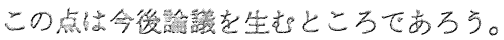
なるほど、紀元前のオーストロアジフ系 およびオーストロネジア系諸族の人的,

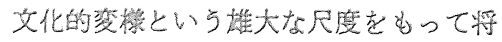
来壳計るなら，䔲者の鮵は正しいたるう。 しかし数十年間という短期的展黛に立っ

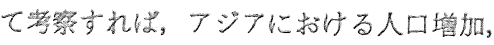
食福需給関係，南北間の生活格差，工菜 圂への学謿力移動等の都条件が複合し, 中国より南南アジアの人口が北進する 日がくるかもしれない。過去にあったと 同粎の中国の南進が数十年先の将来入向 って持綂すると予期するには余りに好現 代の経济・社会の变化要素が複雑化して いる。より一屏切实な問題は菓南フジア 諸国民が域内の少数民族とどのように共 存するかということであろう。日本の経 斎進出から山間民族自立閣争までをふく んだ多民族国家の姿に焦点を合せて将来 を兒通すべきてあるう。

第三に「越南型」と「等瀜型」の2 整

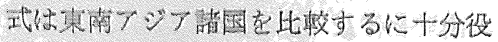
林面か疑わしい。これらの型式は， 1.中国移民，2.中国文化，3. 移住国の先

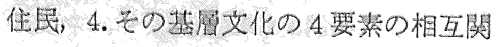
㛊によって構成されているが，多民族，

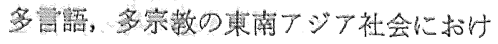

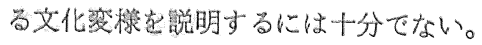
别の尺度として河部利夫教授（『華僑』，

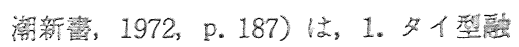
合社会，2.フィリピソ型混合社会，3.? レーシフ型複合社会の 3 型式堂誉け゚，女 化瓷楼の立埸から比故教察している。か

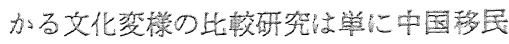
と地元民との接触関係に止まらず，眠に 同化した中国系人と新客，山间部住民と 平野部住民，都市進出の日本人と新㠘独

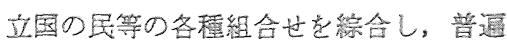
化すべきのであろら。したがって， \& しこの䌨合化と普遍化を求めるならば, 関係各民族社会の文化襍合要素定整理番 号化してコンピューターに記憶させ，精 神的，物貿的生活稼式の大小の格差によ

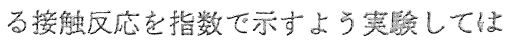
いか力心をのか。

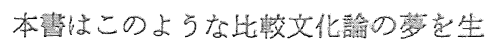
みだす程，文化接触についての多種多棈 な教示を歷史学徒に与えてくれる。一䟽 を怙すすめしたい。

〔市川健二郎】

（遭絡先

東宗水産大学社会科学研究室）

\section{Stephen FitzGerald} \section{China and the Overseas} Chinese: A study of $\mathrm{Pe}$ king's Changing Policy, 1949-1970.

Cambridge University Press, 1972, 210pp., notes, bibliography, index.

本俥は1949年から1970年までの中国華 価政策克在外邦人政策と引揚同胞政策と に大別して考察したユニークな研究箅で ある。著者はオーストラリア国立大学極 
東史学科研究買として, 同大学からこの 研究のための調查葙总得て柬南アジア, 香港，中国本土を旅行し資料䒯蒐策した， とくに文化大革命期の1968年 1 2月の 間, 中国に滞在して僑務政策芝調查し, また香港の Union Research Institute で 1949〜1968年にわたる約 5 万部の各種新 聞, 雑誌を閲覽し, 関係記事克鬼筑した。 著者は序文末尾に C. P. Fitz Gerald，J. D. B. Miller, Wang Gungwu 各教授の 指導に対して謝辞克戴せているが，そも そも彼は1965年にオーストラリア軍の ヴェトナム派兵に抗議して勤め先だった 外務省芯辞職し，この大学で中国語と萃 僑問題艺勉強した人物であり, その研究 成果ををとめたものが本畫である。な打 1973年1月, 嚾か34歳で著者は中国駐在 の初代オーストラリア大使に任命された。 本䡒の内容は次の10音に分れる。

1. 序諭

第 1 篇: 国内の展望

2. 僑務行政, 3. 在外邦人との連絡, 4. 国内僑務政策 : 1949 1966年

第 2 篇 : 在外華僑政策

5. 植层地の黄産, 問題の所在, 僑務 政策：1949～1954年，6. 華僑自決，国 籍問題, 平和共存 : 1954 1956年, 7. 政 策の再检討：1956年, 外国為替, 華僑教 去，8.脱植民地体制への試行，9.文 化大革命，批判㕝受ける龩僑政策， 10 . 萃偪共産主㴽, 外交政策

付表：A. 東南アジア華僑推定人口， B. 華僑事務閣係組職図表, C. 僑務委 員会第 3 期委員名簿, D. 国内華僑農場 一覧表

各章つ内容を紹介しよう。1. 序䜽。
在外孪僑人口について台北側は1830万人 （1969年兒在)，北京側は1174万人（1953 年現在)と推計し, 後者は香港とマカ才 在留者艺龩僑の籍圈外の「同胞」と称し

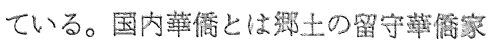
族や㷌国者や留学生を総称したもので, その人口は1200 1300万゙人に邆し, 内別, 広東省 640 万人, 福建省 200 万人, 広西, 管南等の各省合尌 $300 \sim 400$ 万人分布し ている。1909年に国籍法苍制定して在外 同胞の生命財璴の保護に策出してから, 1954年にインドネシアと二面国籍防止恊 定を結ぶに至るまで, 中国は血統主涂の 立埸克とってさた。しかし祴前の努力に 比べると, 新中国の在外制人保䜞の関心 はむしろ低かった。

第 1 篇: 国内の擘望。2. 憍務行政。 帰国華僑は少数民族自治区と似た独自の

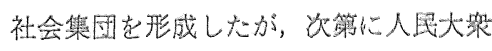
の社会へ同化してい的た。俉務然員会は 第 1 期 50 名（1949 年選出）、籍 2 期58名 (1957 年改選)，符 3 期 63 名 (1959 年改 選）の委員て斟成され，その主任には19 59年まて何番凝が，䋩いて息子の麿承志 が選ばれた。しかし同年以後の主任と委 員との改選について，人居日報は全く揭 載しなくなった。この中央要員会の下に 省媝員会または我事処があり，さらにそ の下に県の僑務課がある。しかし在外䩸 僑に関する政策は外交部（外枒省）の所

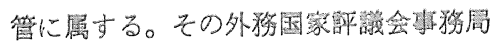
副主席克僑務娄員会副主任康承志が莱任 し, 華僑清年同盟組織走利用して湤外に おける平和推護運動を推進した。すた国 内にあっては，党中央委員会統一戦線工

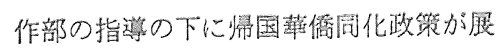


開しだ。

3. 在外邦人との連絡。本土と在外同 胞との菼流は1954年に中国人民対外文化

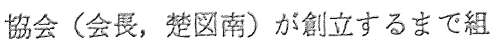
織化されず，水客といら瓜脚を個人的に 利用して文通や送金等の連絡孛統けてき た。中国政府は北京放送や各種新聞少よ び僑務報（1956年創刊）を通じて，新中 国の社会建䓵に貢献する国内華僑の姿を 在外邦人へ報道し，また国度節や清明節 等に際して一眭少国した華晌も楖土家族 の姿荙東䤭アジアへ伝えたし，東南フジ アの中国人学校と㳳字新聞も本土の紹介 に役立った。

4. 国内简務政策 : 1949 1966年。政 府は1956年以降在外邦人の保讙政策老緩 め, むしろ国内華僑の対策に専心した。 つまり，1950年代初期に土地改革が進む につれて, 鄉土の地主や資本家達はその 地位を唅てて社会主義社会建設のための 労働者となったが，1954年以降脽村開発 や学校・住宅增設事業に華僑の外貨送金 とその資本支利用する途が開かれ，これ らの葙僑資本家は改めて特別扱いされる

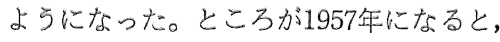
華僑多一般人民大揫と平等に报うべぎ といら翡が高まり, 反右派闘争が進むに つれて問化刘策が拡まった。ささらに1960 年に弪りインドネシフから10万人の引掦 堵を收容した㭙，海外での資本主溥社会 の生活を改如，新中国の社会主禖の社会 建捡に慈加させる途走闻いた。

第 2 篇: 在外䩸偪政策。5. 植民地の 遗童, 問题の所在, 僑敄政策 : 1949 1954年。政府は1951年に柬南アジア在留 同胞人反帝国主義受国連合戦線への參加
を呼びかけたが，1954年になり，本国人 の植民地の忠誠といった旧盟孛廃し，現 住民社会への中国系人の融含を奖码する 政策をとった。したがって，マラヤの抗 英ゲリラ戦も元来中国共痖党の指令によ

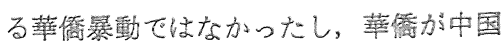
の第 5 列としての役割を果したもので なかった。現に1954年以降の中国は二重 圂籍解消に努め, 現住地社会への萃唀同 化を唱道していたし，引掦同胞の国内て の社会復潩に全力を注いていた。

6. 華慆自決, 国籍問題, 平和共存: 1954 1956年。中国政付は1954年加ら平 和共存支唱え, 萃僑の現住地への㷌化起 すすめ, 従来の在外同胞保護の血統主䣡

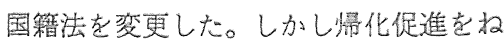
らった中国・インドネシア国籍協定は失 效し、インドネシア国籍を取得した後で も中国系人は相变らず種差別学受けた。 中国は1956年にビルマ帰化の中国系人を もはや同胞と呼ばない旨莸明らがし， さらにシンガポール国籍の中国系人が現 住国へ忠誠を尽すように説いた。好れど も同年 8 月, 南ヴェトナム在留萍僑が強 制帰化走命ぜられた時に，僑務委員会主

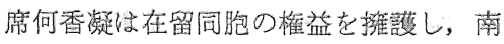
ヴェトナム政府へ哴冓に抗㘺した。

7. 政策の丽榆討, 1956年：外圂為替,

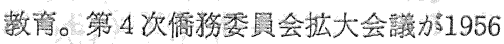
年6月に北京で開催されたが，その席上 で僑務委員会副主任方方は「国内僑務工 作の若干政策」という報告の中で, 闰年 までに激增した香港やマニラ経由の外貨 非合法送金と華僑留学生の外货送金によ る留学生活の実態を取上げた。彼による と, 国内華憍の外貨依存の生活は人民大 
洜の針路に反するものであった。この論 議は1957年の反右派闑争まで発展した。

8. 脱植民地体制への試行。在外邦人 の自決という脱植民地体制を織込んだ 1957年の僑務政策の下で，中国政府は，

1. 現住地国籍の取得, 2. 現住国への 内政不干渉, 3. 慢国者の社会復带の 3 大方剑老揭げ，インドネシアから1959〜 1960年に，インドから1963年に引揚げた 帰国華僑の融合に努力した。この3大方 針によって陳毅外相は東南アジア華僑問 題の全面的な解決をねらったが，人種対 立の問題は必ずしも好転しなかった。19 61～1966年の 6 年間に僑務委員会主任麿 承志㤬在外邦人の自立州化党促進し，華 僑第 5 列, 植民地体制等の疑惑老取除こ うとした。

9. 文化大革命 : 批判支受けた華僑政 筑。この革命で外交政策を攻慗された佮 務委買会は，1966年以降次第に業務起縮 少して，1968年末に解散するに至った。 主任䑁承志も1967年7月以来, 政界加 その姿支消し去った。篬承志批判の発端 俚彼の1951年に述べた次の語であった。 「華僑は少数民族と翼る。華僑が自身の 手で革命を実行しても，民れは決して成 功するに至らないだろう」。ころが造 反派の意見では，華僑は常に本国と連带 関係にある在外少数民族であり，マラヤ では少数民族の生活を目衛するために大 棌闑争に参加してきた。しかるに，㦄承 志主任は䦥争途上にあったマラヤとイン ドネシアの同胞を帰国させるという反革 命政策支とり,さらに世界各地から総計 $300 \sim 400$ 万人の華僑古向 7 ～8 年間に 本国へ引揚げる計画を発表した。
このような僑務政策批判の運動は北京 から上海, 福建, 広東へ飛火し, さらに 香港, ラングーン, ジャカルタヘと拡散し た。僑務報は1966年より停刊となり，国

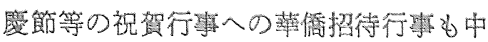
止となりまた「龩僑」の2字まで它飲 食店, アパート，開拓村の看板和ら拭い 去られた。北京では，1968年までに㷌国 華僑のプルジョワ思想起追放し，プロレ タリフ思想克简成守る学習組織が生れ, 同年11月にはインドネシフ国籍閣係躇法 令が廃止された。在外邦人に刘盯る北京 側の関心が高まる中で，1969年5月には

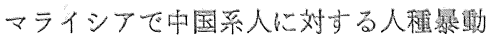

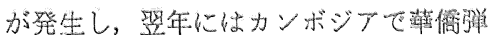
压がみられた。他方，中国国内では1969

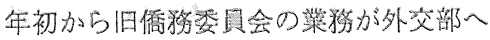

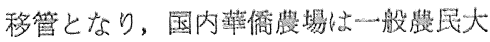
装の農場へ, 鞋僑学校は一般学校へ移行 し, 画者間の差别待遇は全くなくなった。 そして1970年10月に政府は「㽝国藂僑が アジフ民族の反米帝国主濦闘争克支持す るよう」北京から各国へよびかけた。

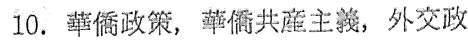
策。文化大革命の風がしず寺った後で中 国政府は再び在外邦人の悟化，自決と中 小諸国の民族解放骤動支持走哀明し，平 和共存路線克喝道している。東洞フジフ に住む中国系人の多くは此権主䣡者では

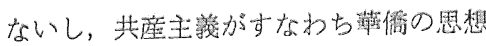
でもない。しかし現住地社会に扰ける中 国系人差別の舞運が解消しないがり，

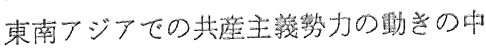
で，華僑が果す役制は引繶さ注目され， また警諓されるであるう。アジフ・ナシ ヨナリズムの洞中にある複雑な鞾僄問題, 


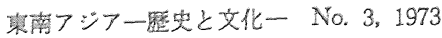

とくに反中国感情の問題は重琶である。

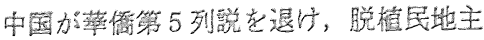
淺体制を贯くならは，蕒南〉ジフ住民の 不安驻弱まるだ弓。しかし，周恩来首 相が1956年に述ぺたように，「常に孪僑 に留る者が存在する」なら结，率僄問題 崺今後共根強く残存するであうう。

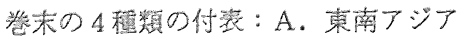

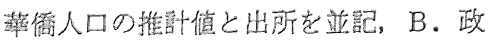
㑏と營中央および民間の各分野にまたが

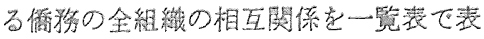

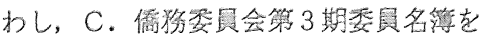

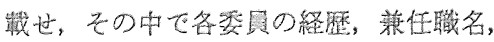
文革当洔の自己批判の有無等赏略号で付

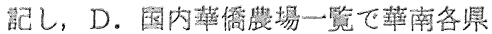

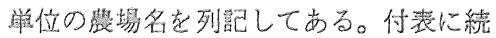
き, 詳細な注 44pp., 文献目録 7pp., 索 引 5 pp. が付いている。

以上の内容艺通韵した感想の第 1 点は 中国本土で得た荎者自身の面接資料と華

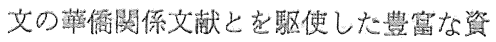
料内容で嘴たされている点である。第 2

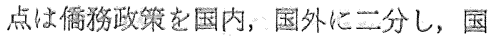
内華僑が新中国湕設に参加古る政策内容 に䇥点起枕いたことである。この二分法 は C. P. FitzGerald 数授の䩸僑史観に

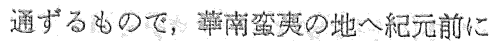

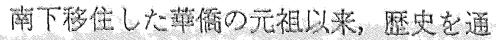

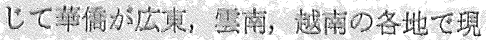
住医と同居し融合したとする見解である。 数授の期陶を受けた Stephenは地方勢 力の統治と新中国の建設に努的る中央政

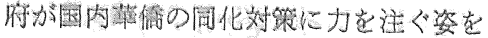
㽤いている。

籍 3 点は文化大革命以前の僑務政策と して政府が在外萃僑の現住国への帰化と
現住国是としての自決を促進した点であ り，在外華俉を「第 5 列」として利用す る政筑をとらず，むしろ脱植民地体削へ の華宬現地化を推進したとみる点である。 しかしながら、これらの僑務政筑とはう らはらに, 北京当局がアジア・太平洋地 区平和傕動連絡委員会の組縗を通して, 域内諸国の反帝国主議運動中新與国内部 の民族解放戦線運嗔を指導していた害実 を見過ごしてはならない。政策面の資料 を中心として在外龩僑を説明した本毒の 内容支生活の実態面を物語る資粦によっ て補足する余地が残されている。

第 4 点は文化大革命期の僑務委員会幹 部等が批判された㸚らいを，かれらの外 交政策上の失政に求める点である。当時， 造反派は劉少奇, 故毅らと共に何䅨㠜, 屬承志ら僑務指導者党批判した。しかし， 周恩来の現外交政筑と文革以前のそれと の間にどのような基本的相㦀点があった であろうか。現に当時姿を消していた厤 承志ら民主諸派系幹部らは今では政界に 復帰している。本畫は恐らく，1971年に 執算し，翌年初比出版されたものであろ。 うが，変貌する1972年の中国政界の動き を記載するに至っていない。読者にとっ ては本書のこの部分の章節が改訂增補さ れる日蒾楽しみに待ちたい。1973年 1 月 に著者は初代オーストラリア大使として 北京へ赴任した。大使としての著者の別 の新蓄を近い将来に或は期待する方がよ いか子しれない。

〔市川健二郎】 